\title{
Age of Feiran basement rocks, Sinai: implications for late Precambrian crustal evolution in the northern Arabian-Nubian Shield
}

\author{
R. J. STERN \& W. I. MANTON \\ Programs in Geosciences, The University of Texas at Dallas, Box 688, Richardson, Texas 75083-0688, USA
}

\begin{abstract}
Basement exposed on the perimeter of the Red Sea was created during the Pan-African event at the end of the Precambrian. Pre-Pan-African crust in the northern part of this region has not yet been identified. This paper reports the results of $\mathrm{Rb}-\mathrm{Sr}$ whole-rock and $\mathrm{U}-\mathrm{Pb}$ zircon dating of gneisses and related basement units from the Wadi Feiran area in the Sinai peninsula, where the existence of such older basement has previously been suggested. A post-tectonic extensional dyke gives a $\mathrm{Rb}-\mathrm{Sr}$ age of $591 \pm 9 \mathrm{Ma}$ with an initial ${ }^{87} \mathrm{Sr} /{ }^{86} \mathrm{Sr}$ ratio of $0.7034 \pm 0.0002$. Rb-Sr whole-rock and thin slab dating of paragneisses gives ages of $c .610 \mathrm{Ma}$ with an initial ${ }^{87} \mathrm{Sr} /{ }^{86} \mathrm{Sr}$ ratio of 0.7035 . A $\mathrm{U}-\mathrm{Pb}$ zircon age of $632 \pm 3 \mathrm{Ma}$ is interpreted as either the time of formation of these gneisses or the age of the crust sampled by protolith sediments. Granodiorite to the east gives a U-Pb zircon age of $782 \pm 7 \mathrm{Ma}$ and is interpreted as representing the westernmost extent of a $780 \pm 50 \mathrm{Ma}$ terrane that extends across Sinai into Jordan. Uplift and erosion of the $780 \pm 50 \mathrm{Ma}$ terrane supplied detritus to flanking terranes in $\mathrm{N}$ and SE Sinai. This region thus acted as a foreland to the younger accretionary and extensional units to the south and west that were active later in the Pan-African event. There is still no evidence for pre-Pan-African basement in the Precambrian units around the northern Red Sea east of the Nile.
\end{abstract}

Formation of the continental crust of NE Africa and Arabia occurred during the end of the Precambrian (450-950 Ma Pan-African Event of Kröner 1984), largely manifesting a telescoped series of island arcs, marginal basins, and accreted terranes (e.g. Gass 1977; Kröner 1985). One of the most remarkable aspects of this episode of crust formation is the apparent lack of involvement of pre-Pan-African continental crust, especially in the basement exposed east of the River Nile. There is no direct evidence that a well-defined stabilized foreland existed anywhere in this region, and there is a paucity of igneous rocks with isotopic signatures indicating the melting of such crust. An important exception to this generalization is the $c .1 .6 \mathrm{Ga}$ Afif Terrane in the S Arabian Shield (Stacey \& Hedge 1984). Even this may not represent a pre-Pan-African foreland, because it is flanked east and west by wide expanses of Pan-African igneous rocks and so may be an 'exotic terrane' (Stoeser \& Camp 1985). It is suggested that c. $0.9-1.2 \mathrm{Ga}$ crust may exist in the southern part of the Eastern Desert of Egypt (El Shazly et al. 1973; El Manharawy 1977 in Cahen et al. 1984). These inferences are based on whole-rock $\mathrm{Rb}-\mathrm{Sr}$ age determinations that either show a large degree of scatter around the regression line (El Shazly et al. 1973) or are unpublished and unavailable (El Manharawy 1977). We suspect that $c .1 .1 \mathrm{Ga}$ crust does exist in the Abu Swayel area (El Shazly et al. 1973) but these ages need confirmation by $\mathrm{U}-\mathrm{Pb}$ zircon studies. The presence of $1.1-2.3 \mathrm{Ga}$ cobbles of granodiorite, quartzite, and marble in the late Precambrian Atud Conglomerate of the Eastern Desert of Egypt indicates that a much older foreland must have been nearby (Dixon 1981), and probably lay just west of the present Nile (Schandelmeir et al. in press). With the exception of Archean basement at Uweinat, $1000 \mathrm{~km}$ west of the principal Pan-African exposures (Klerkx \& Deutsch 1977), this foreland has not been found in situ.

Our ignorance regarding the relationship between
Pan-African and older units severely limits our ability to reconstruct this region's tectonic evolution accurately. One place to look for pre-Pan-African basement is among the gneissic rocks of Afro-Arabia. It is important to know if these gneissic terranes are significantly older than the surrounding greenschist-facies ophiolitic and arc material and so may have represented a continental foreland during the Pan-African orogenies, or if these terranes are simply metamorphosed equivalents of the lower grade rocks. This problem was first addressed in studies of the Egyptian basement, where gneisses are principally exposed in three areas (Fig. 1): (1) Sinai, typified by the area drained by Wadi Feiran; (2) Central Eastern Desert typified by the rocks of Meatiq Dome; and (3) SE Desert, one representative of which is the gneissic terrane surrounding Gebels Migif and Hafafit.

Earlier investigators considered these gneisses to be palimpsests oi much older continental crust (Hume 1934). Schürmann (1966) grouped the Egyptian gneisses into the 'Mitiq Series' which he interpreted to underlie (beneath one or more unconformities) the younger and less metamorphosed parts of the basement. Subsequent studies have not supported these interpretations. Sturchio et al. (1983a) interpreted the Meatiq Dome gneisses to have formed from sheared and recrystallized felsic igneous rocks at 580$625 \mathrm{Ma}$ accompanying the development of a metamorphic core complex. Low initial ${ }^{87} \mathrm{Sr} /{ }^{86} \mathrm{Sr} \quad(c .0 .7030)$ was interpreted to indicate a lack of remelted older continental crust (Sturchio et al. 1983b). Gneisses from the MigifHafafit area have a more complex history. Eleven deformational and five igneous events have been observed (Elbayoumi \& Greiling 1984). A syntectonic tonalite intruded into the gneisses has a U-Pb zircon age of $682 \mathrm{Ma}$ and an initial ${ }^{87} \mathrm{Sr} /{ }^{86} \mathrm{Sr}$ of 0.7024 (Stern \& Hedge 1985). Metasediments and foliated granites from the region give values of $\varepsilon_{\mathrm{Nd}}$ (at $750 \mathrm{Ma}$ ago) of +6.6 and +5.4 (Harris et al. 


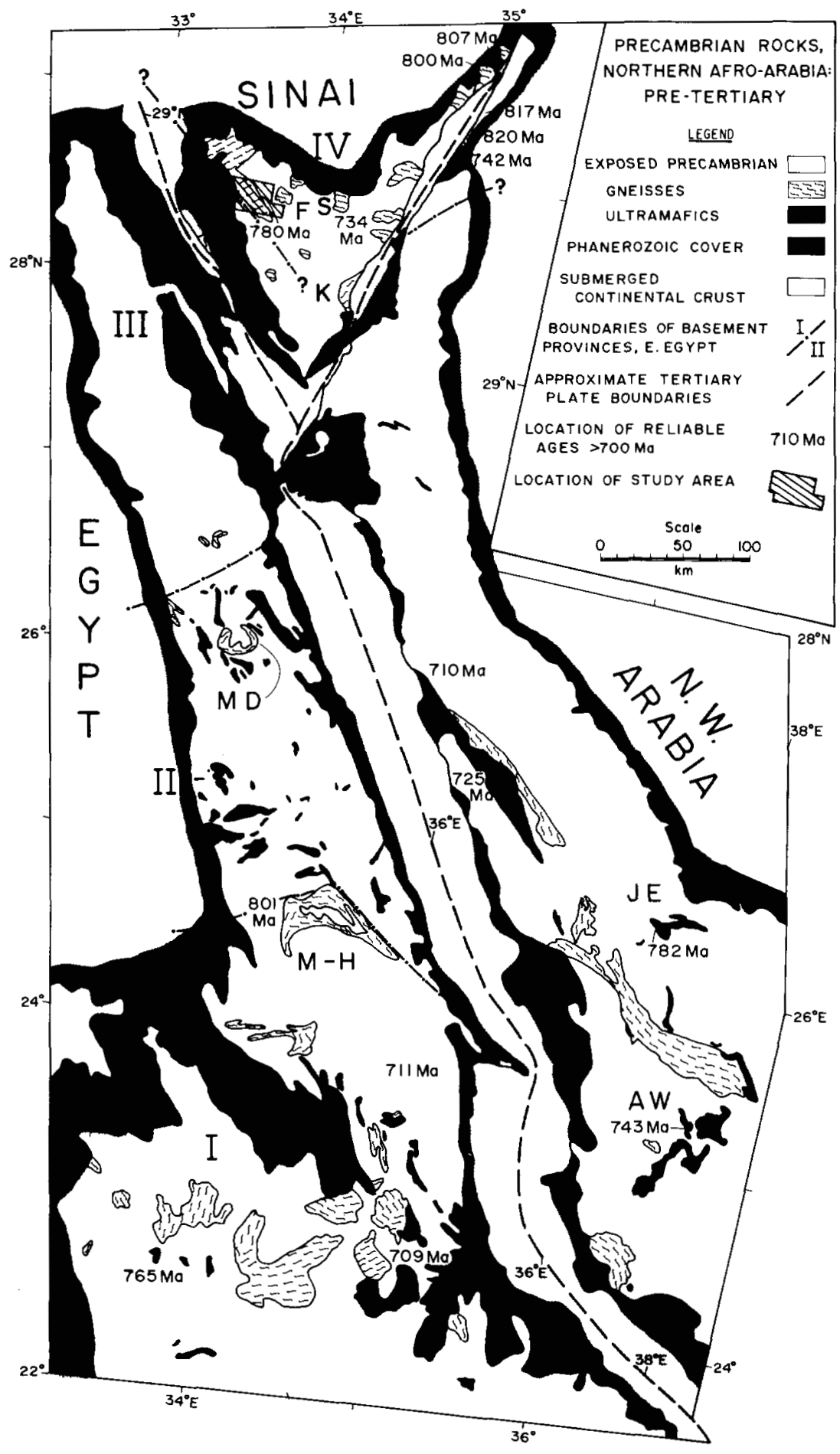

Fig. 1. Locality map of NE Africa, Sinai, and NW Arabia, modified to show the distribution of basement terranes prior to opening of the Red Sea and Gulf of Suez. Also shown are the location of gneisses and associated high-grade rocks and serpentinized ultramafics. Reconstruction includes $110 \mathrm{~km}$ translation along the Dead Sea-Gulf of Aqaba strike slip system and $30 \mathrm{~km}$ closure of the Gulf of Suez (Freund et al. 1970). The designation of basement province boundaries in the Eastern Desert of Egypt are those of Stern \& Hedge (1985); designation of basement province IV, Sinai, is a new result. Sources for the geological compilation are as follows: Eastern Desert of Egypt, El-Ramly 1972; Sinai, Eyal et al. 1980; Jordan, Bender, 1974; NW Arabia, Johnson, 1983; Clark, 1985. Abbreviations for regions discussed in the text are as follows: M-H, Migif-Hafafit; MD, Meatiq Dome; F, Feiran; JE, Jebel Ess ophiolite; AW, Al Wask ophiolite; K, Wadi Kid; S, Sa'al. Also shown are the ages and locations of more reliable whole-rock $\mathrm{Rb}-\mathrm{Sr}, \mathrm{U}-\mathrm{Pb}$ zircon, or $\mathrm{Sm}-\mathrm{Nd}$ dates with ages greater than $700 \mathrm{Ma}$. Sources of geochronological data: Hashad et al. 1972; Halpern \& Tristan 1981; Dixon 1981; Bielski 1982; Jarrar et al. 1983; Claesson et al. 1984; Hedge 1984; Stern \& Hedge 1985; present study.
1984), a further indication that pre-late Precambrian continental crust was not involved in generating the Migif-Hafafit gneisses.

The gneisses of Wadi Feiran represent an excellent opportunity to investigate further the origin of Pan-African high grade terranes. This paper reports our,efforts to determine the timing of the principal crust-forming events in the Feiran area and presents our interpretation of their significance for deciphering late Precambrian crustal evolution in $\mathbf{N}$ Afro-Arabia.

\section{Geological setting and previous work}

The Feiran gneisses are located near the NW corner of exposed basement in Sinai (Fig. 1). The gneisses and associated synorogenic granodiorites are bracketed to the north and south by post-orogenic granites (Fig. 2), dated elsewhere in Sinai and Egypt at 570-600 Ma (Bielski et al. 1979; Halpern 1980; Fullagar 1980; Halpern \& Tristan 1981; Stern \& Hedge 1985). El Gaby \& Ahmed (1980) interpreted the Feiran gneisses to represent a thick (>5000 m) 


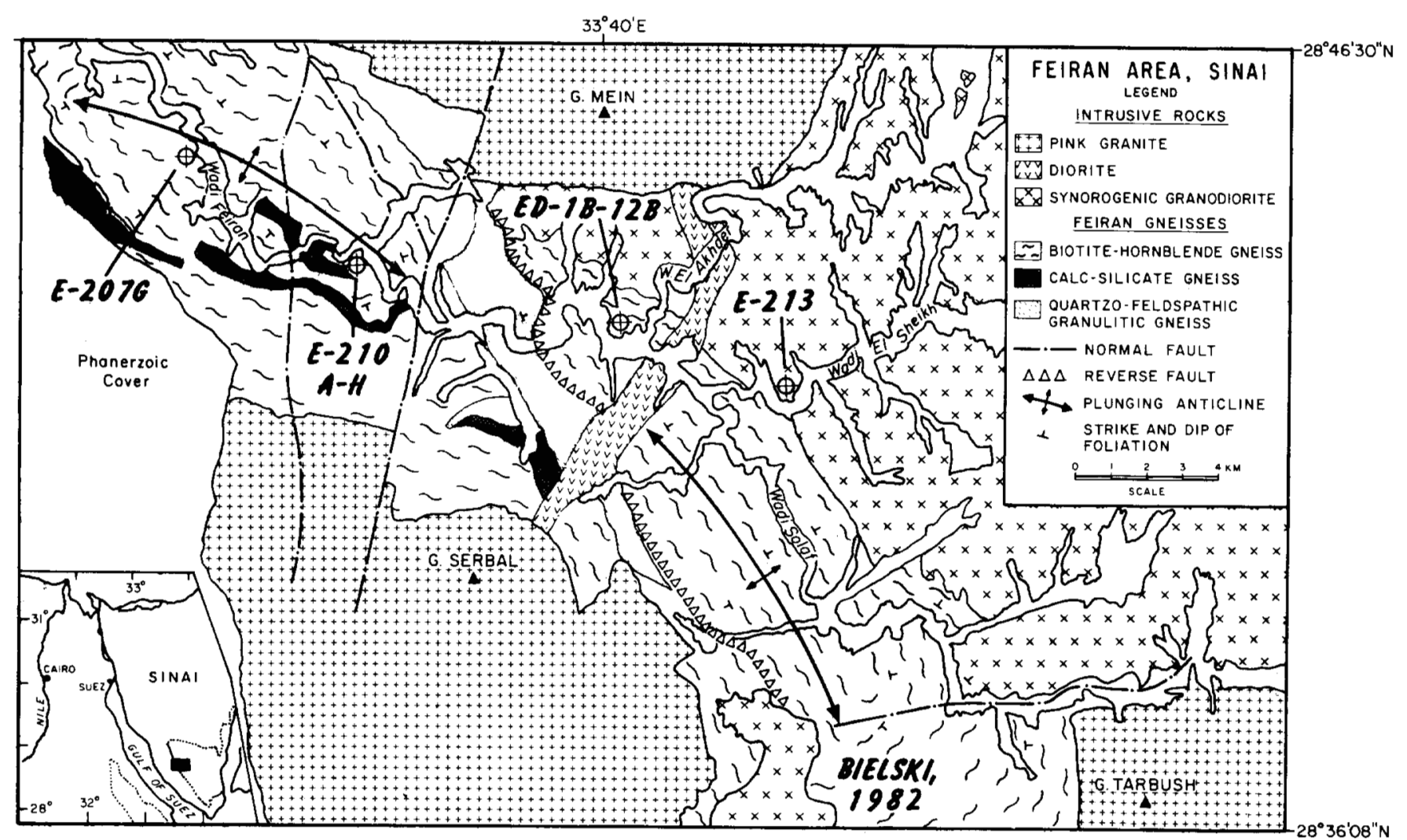

Fig. 2. Geological map of the area around Wadi Feiran, modified after El-Gaby \& Ahmed (1980), showing the distribution of samples analysed here along with the approximate location of the suite analysed by Bielski (1982).

sedimentary succession, with minor mafic intercalations, that was folded into three NW-SE trending anticlines overturned to the west and separated by NW-SE trending thrust faults.

Previous investigators have considered the Feiran gneisses to be of pre-Pan-African age (Schürmann 1966; Shimron 1980). Shimron (1980) argued that the gneisses formed prior to $1100 \mathrm{Ma}$ largely on the basis of unpublished geochronological data. Bielski (1982) reported a $\mathrm{Rb}-\mathrm{Sr}$ whole rock age of $643 \pm 41 \mathrm{Ma}$ and an initial ${ }^{87} \mathrm{Sr} /{ }^{86} \mathrm{Sr}$ ratio of $0.7032 \pm 0.0007$ for five samples of gneiss collected within the present study area. The gneisses are flanked to the east by an extensive body of foliated granodiorite and are dissected by abundant $\mathrm{N} 30^{\circ} \mathrm{E}$ trending bimodal dykes (Voegeli 1985). The latter postdate all compressional deformation and are manifestations of late regional extension (Stern 1985).

\section{Analytical techniques}

Samples for $\mathrm{Rb}-\mathrm{Sr}$ whole-rock geochronology were processed according to standard procedures, including cleaning, crushing, and column separation. $\mathrm{Rb}$ and $\mathrm{Sr}$ were analysed by isotope dilution on the UTD 6"- and 12"-radius solid source mass spectrometers. Total processing blanks are $\leqslant 3 \mathrm{ng} \mathrm{Sr}$ and $\leqslant 0.1 \mathrm{ng} \mathrm{Rb}$. Age regressions were carried out using the York II treatment of data (York 1969) and all uncertainties are $2 \sigma$. Samples containing zircons were crushed, sized, and the nonmagnetic zircons isolated. These were cleaned by boiling in $\mathrm{HNO}_{3}$ and $\mathrm{HCl}$ before dissolution in Krogh-type bombs. Total processing blanks for $\mathrm{Pb}$ are $0.5-1.0 \mathrm{ng}$. Analyses were carried out on the UTD $12^{\prime \prime}$-radius instrument.
Regression calculations to concordia are those of Ludwig (1980); uncertainties are at the $95 \%$ confidence level. A lower intercept of $15 \pm 20 \mathrm{Ma}$ was forced; the justification for this procedure for dating rocks in the Arabian Shield has been presented elsewhere (Stacey et al. 1984).

\section{Results}

The location of the four suites studied here along with that of the suite analysed by Bielski (1982) are shown in Fig. 2. analytical results are listed in Tables 1 and 2 and are presented in Figs 3 and 4 . The $\mathrm{Rb}-\mathrm{Sr}$ results will be discussed first.

The late dyke swarms are represented by 10 samples, ED-1B to $12 \mathrm{~B}$, taken from a single composite basaltrhyolite dyke (Voegeli 1985). These give an excellent spread in ${ }^{87} \mathrm{Rb} /{ }^{86} \mathrm{Sr}$, defining an age of $591 \pm 9 \mathrm{Ma}$ and an initial ${ }^{87} \mathrm{Sr} /{ }^{86} \mathrm{Sr}$ ratio of $0.7034 \pm 0.0002$ (Fig. 3a). The MSWD of 1.8 is less than the F-variate of 2.02 , so this is an isochron age, taken to represent the time of emplacement of this and other NE-trending dykes in the region.

Eight samples of hornblende-biotite quartzo-feldspathic gneiss were collected from outcrops separated by a total distance of no more than $400 \mathrm{~m}$. These rocks were mapped as metasediments by El Gaby \& Ahmed (1980); we describe these as paragneisses in the field. The eight points define a regression line with an age of $614 \pm 27 \mathrm{Ma}$ and an initial ${ }^{87} \mathrm{Sr} /{ }^{86} \mathrm{Sr}$ ratio of $0.7034 \pm 0.0003$ (Fig. 3b). The MSWD of 4.7 is significantly higher than the F-variate of 2.18, indicating that this is not an isochron. Nevertheless, the low intercept and moderate degree of scatter indicate this age is 
Table 1. $R b, S r$, and ${ }^{87} S r /{ }^{86} S r$ data

\begin{tabular}{|c|c|c|c|c|}
\hline & $\mathrm{Rb}(\mathrm{ppm})$ & $\mathrm{Sr}(\mathrm{ppm})$ & ${ }^{87} \mathrm{Rb} /{ }^{86} \mathrm{Sr}$ & ${ }^{87} \mathrm{Sr} /{ }^{86} \mathrm{Sr}^{1}$ \\
\hline \multicolumn{5}{|l|}{ 1. Dyke } \\
\hline ED-1B & 78.7 & 699 & 0.326 & $0.70597 \pm 6$ \\
\hline 3B & 81.4 & 639 & 0.368 & $0.70639 \pm 7$ \\
\hline $4 B$ & 101 & 518 & 0.564 & $0.70819 \pm 8$ \\
\hline $6 \mathrm{~B}$ & 164 & 35.0 & 14.05 & $0.82307 \pm 13$ \\
\hline $7 \mathrm{~B}$ & 184 & 27.2 & 20.38 & $0.87689 \pm 8$ \\
\hline $8 \mathrm{~B}$ & 182 & 16.2 & 34.19 & $0.99169 \pm 10$ \\
\hline $9 \mathrm{~B}$ & 166 & 22.1 & 22.46 & $0.88791 \pm 23$ \\
\hline $10 \mathrm{~B}$ & 102 & 573 & 0.515 & $0.70765 \pm 7$ \\
\hline $11 \mathrm{~B}$ & 78.4 & 687 & 0.330 & $0.70620 \pm 7$ \\
\hline $12 \mathrm{~B}$ & 76.3 & 672 & 0.328 & $0.70631 \pm 7$ \\
\hline \multicolumn{5}{|l|}{ 2. Gneiss } \\
\hline E-210A $A^{2}$ & 35.5 & 342 & 0.283 & $0.70606 \pm 9$ \\
\hline $\mathrm{AD}$ & 63.1 & 326 & 0.560 & $0.70862 \pm 9$ \\
\hline $\mathrm{AL}$ & 18.4 & 346 & 0.154 & $0.70506 \pm 5$ \\
\hline $210 \mathrm{~B}$ & 80.8 & 309 & 0.757 & $0.71000 \pm 7$ \\
\hline $210 \mathrm{C}$ & 53.4 & 395 & 0.391 & $0.70677 \pm 7$ \\
\hline $210 \mathrm{D}$ & 36.2 & 393 & 0.267 & $0.70587 \pm 7$ \\
\hline $210 \mathrm{E}$ & 19.4 & 407 & 0.138 & $0.70445 \pm 6$ \\
\hline $210 \mathrm{~F}$ & 16.8 & 313 & 0.155 & $0.70518 \pm 10$ \\
\hline $210 G$ & 46.0 & 466 & 0.286 & $0.70595 \pm 7$ \\
\hline $210 \mathrm{H}$ & 82.1 & 482 & 0.492 & $0.70775 \pm 11$ \\
\hline \multicolumn{5}{|c|}{ 3. Single samples } \\
\hline E-210 Peg. & 136 & 161 & 2.44 & $0.72430 \pm 7$ \\
\hline $207 \mathrm{G}$ & 36.5 & 358 & 0.295 & $0.70654 \pm 7$ \\
\hline 213 & 74.3 & 299 & 0.718 & $0.71139 \pm 6$ \\
\hline
\end{tabular}

${ }^{187} \mathrm{Sr} /{ }^{86} \mathrm{Sr}$ normalized to $\mathrm{E}+\mathrm{A} \mathrm{SrCO}_{3}{ }^{87} \mathrm{Sr} /{ }^{86} \mathrm{Sr}=0.70800$.

${ }^{2} \mathrm{E}-210 \mathrm{~A}, 210 \mathrm{AD}$, and $210 \mathrm{AL}$ are whole rock, dark layers, and light layers, respectively, of sample E-210A.

probably close to the true age; whether variable initial ${ }^{87} \mathrm{Sr} /{ }^{86} \mathrm{Sr}$ or metamorphic disturbances are responsible for the scatter is not clear. Analyses of adjacent 5-cm-thick light and dark layers from E-210A (Fig. 3b inset) define an isochron age of $610 \pm 44 \mathrm{Ma}$ with an initial ${ }^{87} \mathrm{Sr} /{ }^{86} \mathrm{Sr}$ of $0.7037 \pm 0.0002 \mathrm{~K}$-feldspar-rich pegmatite from this locality (E-210 peg.) gives model ages of $606 \mathrm{Ma}(\mathrm{I} . \mathrm{R} .=0.7032)$ to $586 \mathrm{Ma}$ (I.R. $=0.7039$ ).

Zircons were separated from a gneiss sample (E-207G) that has a very similar field appearance and petrography to the samples dated by $\mathrm{Rb}-\mathrm{Sr}$ whole-rock techniques. The zircons were few in number and of small size ( $<140$ mesh). Microscopic examination disclosed that all were euhedral with no apparent overgrown or metamict cores. The single fraction analysed gave a nearly concordant model age of

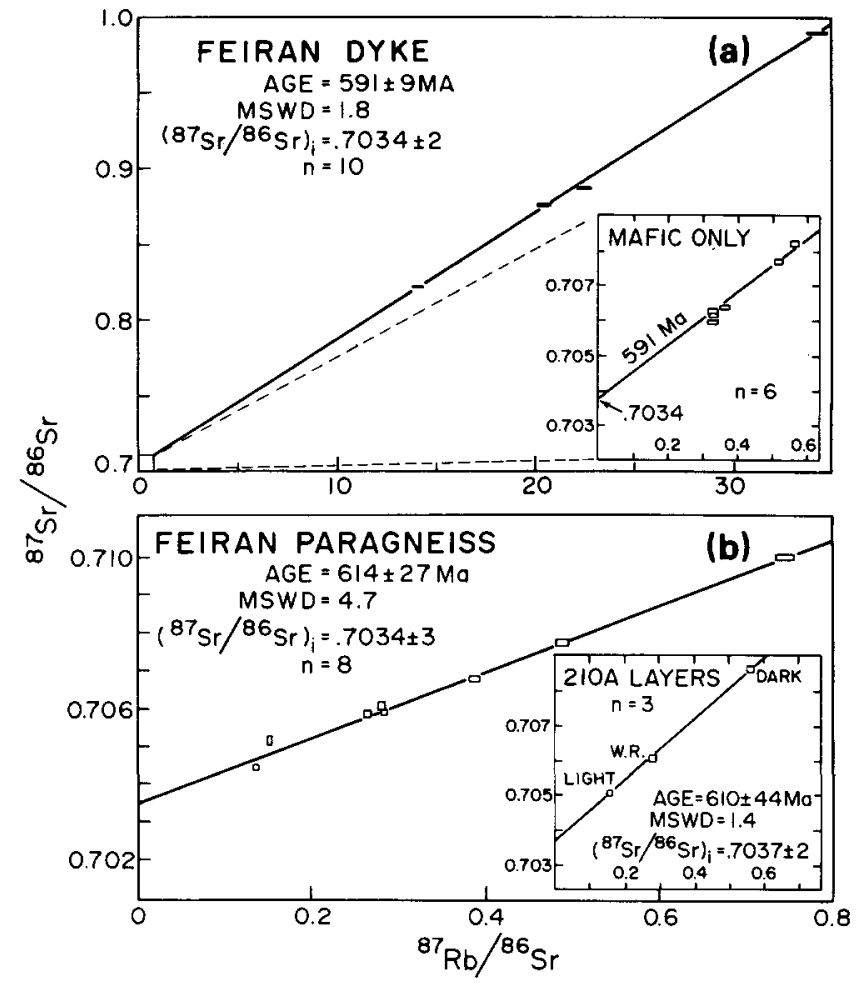

Fig. 3. Rb-Sr whole rock isochron diagrams for rocks from the Feiran area. (a) Late extensional dyke; (b) Paragneiss (inset shows results for thin-layer dating of one sample).

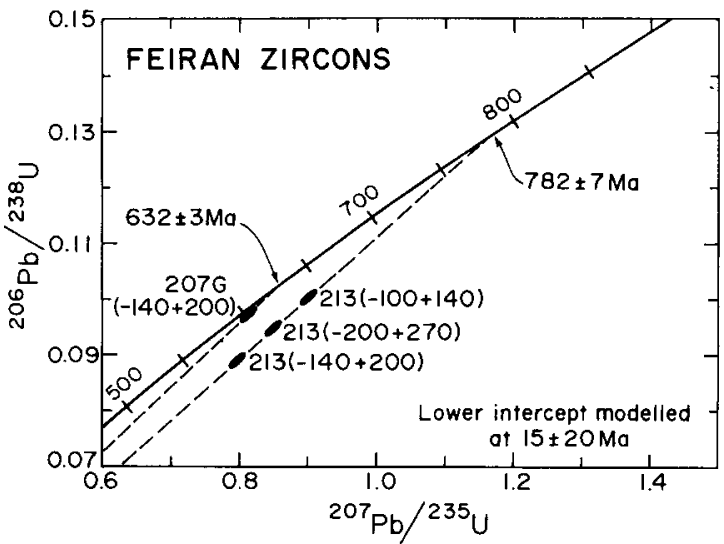

Fig. 4. $\mathrm{U}-\mathrm{Pb}$ zircon concordia diagram for rocks from the Feiran area.

Table 2. $U, P b$, and $\mathrm{Pb}$ isotopic composition data

\begin{tabular}{|c|c|c|c|c|c|c|c|}
\hline \multirow[b]{2}{*}{ Sample, mesh } & \multicolumn{2}{|c|}{ Concentration } & \multicolumn{2}{|c|}{ Measured $\mathrm{Pb}$ ratios } & \multicolumn{3}{|c|}{ Corrected ratios } \\
\hline & $\mathrm{U}$ (ppm) & $\begin{array}{l}\text { ntration } \\
\mathrm{Pb}(\mathrm{ppm})\end{array}$ & 206/204 & $\begin{array}{c}\text { Po ratios } \\
207 / 206\end{array}$ & $207 \mathrm{~Pb} / 235 \mathrm{U}$ & $206 \mathrm{~Pb} / 238 \mathrm{U}$ & $207 \mathrm{~Pb} / 206 \mathrm{~Pb}$ \\
\hline \multicolumn{8}{|l|}{$207 \mathrm{G}$ paragneiss ${ }^{1}$} \\
\hline $\begin{array}{r}-140+200 \\
213 \text { granodiorite }\end{array}$ & 434.4 & 40.59 & 7812 & 0.06255 & 0.8096 & 0.09662 & 0.06077 \\
\hline$-100+140$ & 475.8 & 51.06 & 2667 & 0.07054 & 0.9010 & 0.1002 & 0.06520 \\
\hline$-140+200$ & 552.9 & 53.20 & 1873 & 0.07279 & 0.7968 & 0.08883 & 0.06506 \\
\hline$-200+270$ & 629.0 & 63.32 & 6211 & 0.06736 & 0.8499 & 0.09476 & 0.06505 \\
\hline
\end{tabular}

${ }^{1}$ Corrected for common lead at $620 \mathrm{Ma}$ (Stacey \& Kramers 1975).

${ }^{2}$ Corrected for common lead at $790 \mathrm{Ma}$ (Stacey \& Kramers 1975). 
$632 \pm 3 \mathrm{Ma}$ (Fig. 4). Using this age and the $\mathrm{Rb}-\mathrm{Sr}$ data in Table $1, \mathrm{E}-207 \mathrm{G}$ had an initial ${ }^{87} \mathrm{Sr} /{ }^{86} \mathrm{Sr}$ ratio of 0.7039 .

Strongly foliated granodiorites comprise an extensive terrane east of the paragneiss. Three fractions of zircons separated from sample 213 were euhedral, with no obvious overgrown cores or metamict components. Analytical results were quite discordant but defined an age of $782 \pm 7 \mathrm{Ma}$ (Fig. 4). Interpreting this as the crystallization age, the $\mathrm{Rb}-\mathrm{Sr}$ data in Table 1 indicate that this granodiorite had an initial ${ }^{87} \mathrm{Sr} /{ }^{86} \mathrm{Sr}$ ratio of 0.7034 .

\section{Discussion}

There are two possible interpretations of the gneiss zircon age of $632 \mathrm{Ma}$. This age represents either the time of the metamorphism that formed the gneisses, or the time of igneous activity sampled by the sedimentary protolith. Selection of the correct interpretation is critically dependent on a better understanding of the nature of the gneiss protolith. The gneisses are quartzo-feldspathic and lack minerals that would be found in metamorphosed polycyclic sediments, especially aluminosilicates and garnet; there are no quartzites among the gneisses. The protolith for the Feiran paragneisses was probably very immature, volcanigenic wackés or perhaps lithic arenites interbedded with felsic tuffs. Such sediments predominate in the late Precambrian of this region and were deposited very rapidly following consolidation of their source rocks (Engel et al. 1980; Massey 1984). The zircons from the gneiss may have formed in granitic rocks that cooled and were eroded just prior to the deposition of these sediments and tuffs; in this case, the $632 \mathrm{Ma}$ age corresponds to pre-metamorphic igneous activity and the time of gneiss formation is better defined by the $\mathrm{Rb}-\mathrm{Sr}$ whole rock and thin-slab ages of 610-615 Ma. Alternatively the $632 \mathrm{Ma}$ age dates the gneiss-forming event. This could be the result of either the loss of all lead from detrital zircons or growth of new zircons in metasediments that were originally deposited free of zircon. In this case, the $632 \mathrm{Ma}$ refers to peak metamorphic conditions with 614,610 , and $606-586 \mathrm{Ma} \mathrm{Rb}-\mathrm{Sr}$ ages corresponding to later times of cooling through whole-rock, thin layer, and K-feldspar blocking temperatures.

In either interpretation, there was very little time between the igneous activity and sedimentation resulting in protolith formation, metamorphism, and uplift. This is demonstrated by the relatively low initial ${ }^{87} \mathrm{Sr} /{ }^{86} \mathrm{Sr}$ ratios $(0.7034-0.7039)$ of the gneisses and the overlap between the ages given by $\mathrm{U}-\mathrm{Pb}$ zircon, whole rock $\mathrm{Rb}-\mathrm{Sr}$ and thin slab $\mathrm{Rb}-\mathrm{Sr}$, and the model age of the late pegmatite. Regardless of which interpretation is preferred, the gneiss formed at or just after $632 \mathrm{Ma}$. The high-grade metamorphic event must have been complete by the time that the $591 \pm 9 \mathrm{Ma}$ dykes were emplaced. The tectono-magmatic episode responsible for gneiss formation may have been related to the 610-630 Ma compressional events important in the evolution of the Central and NE Deserts of Egypt (Stern \& Hedge 1985). The major NW-SE trending structures clearly developed during this event.

The $780 \mathrm{Ma}$ age from the Feiran granodiorite is especially significant for regional tectonic reconstructions but is more difficult to interpret within the local geological context. The contact between the paragneisses to the west and the granodiorite parallels the paragneiss structural trends and on the basis of the geochronological date must either be an unconformity or a fault. This contact has not been identified in the field as either, probably due to overprinting by the $610-630 \mathrm{Ma}$ event. More detailed structural studies will be required to resolve this problem.

The granodiorite is the westernmost known representative of $780 \pm 50 \mathrm{Ma}$ crust which extends across Sinai into Jordan but has not been found in adjacent portions of Egypt or Arabia. In Jordan, sillimanite-garnet schists, 2-mica granite, and paragneiss give $\mathrm{U}-\mathrm{Pb}$ zircon ages of 742-820 Ma (Jarrar et al. 1983). Pelitic schists from a high grade metamorphic terrane around Elat, Israel, give whole-rock $\mathrm{Rb}-\mathrm{Sr}$ ages of $807 \pm 35 \mathrm{Ma}$ (I.R. $=0.7032 \pm$ 0.0005 ; Halpern \& Tristan 1981) or $800 \pm 43$ Ma (I.R. = $0.7030 \pm 0.0006$; Bielski 1982). Metavolcanic rocks of the Sa'al Group in Sinai yield $\mathrm{Rb}-\mathrm{Sr}$ whole-rock ages of $734 \pm 17 \mathrm{Ma}$ (I.R. $=0.7029$; Bielski 1982). There is thus clearly an extensive terrane of $780 \pm 50 \mathrm{Ma}$ basement underlying much of $\mathrm{N}$ Sinai and S Jordan. These are the oldest reliable ages from this region, and suggestions of ages greater than $1100 \mathrm{Ma}$ (Shimron 1980) cannot be confirmed.

The $780 \pm 50$ Ma terrane in northernmost Afro-Arabia has not been recognized in adjacent terranes immediately to the south and west (Fig. 1). Rocks older than $700 \mathrm{Ma}$ have not been found north of $25^{\circ} \mathrm{N}$ in Egypt in spite of efforts to date the oldest rocks there (Stern \& Hedge 1985). Units older than $700 \mathrm{Ma}$ are quite common in Egypt south of $25^{\circ} \mathrm{N}$ (Fig. 1) and in Sudan (Fitches et al. 1983; Klemenic 1985). In the Arabian Shield, units older than $700 \mathrm{Ma}$ are not common north of $27^{\circ} \mathrm{N}$ (Hedge 1984). To the south, $780 \pm 50 \mathrm{Ma}$ ages are first encountered for the $782 \pm 38 \mathrm{Ma}$ J. Ess ophiolites at $26^{\circ} 20^{\prime} \mathrm{N}$ (Fig. 1; Claesson et al. 1984). Basement dominated by $>700 \mathrm{Ma}$ rocks is only found south of $23^{\circ} 30^{\prime} \mathrm{N}$ in Arabia (Cooper et al. 1979; Fleck et al. 1980; J. S. Stacey pers. comm. 1986).

Further support for the interpretation that $780 \pm 50 \mathrm{Ma}$ crust is common in Sinai and Jordan and absent from terranes immediately to the south and west comes from consideration of initial ${ }^{87} \mathrm{Sr} / 86 \mathrm{Sr}$ ratios. Paragneiss and the dyke analysed have initial ${ }^{87} \mathrm{Sr} /{ }^{86} \mathrm{Sr}$ ratios of $0.7034-0.7039$, similar to the initial ratios for rocks of like age elsewhere in Sinai $(\hat{\mathrm{x}}=0.7040$; Mittlefehldt \& Reymer 1986) but slightly higher than initial ${ }^{87} \mathrm{Sr} /{ }^{86} \mathrm{Sr}$ ratios for rocks of similar age from the Eastern Desert of Egypt (0.7025-0.7035; Stern \& Hedge 1985) or from NW Arabia (0.7028-0.7035; Duyverman et al. 1982; Hedge 1984). The consistently higher initial ${ }^{87} \mathrm{Sr} /{ }^{86} \mathrm{Sr}$ ratios of Sinai basement rocks probably reflects the participation of $780 \pm 50 \mathrm{Ma}$ crust and/or lithosphere in the generation of the Sinai melts. This component was not present during melt evolution in adjacent regions to the south and west.

The juxtaposition of $630 \mathrm{Ma}$ paragneiss against the $780 \pm 50 \mathrm{Ma}$ basement in the Feiran area is especially interesting. This may represent a major crustal boundary within the Precambrian basement, separating 540-670 Ma sialic crust of province III in the NE Desert from $780 \pm 50 \mathrm{Ma}$ basement of Sinai and Jordan that was nevertheless severely overprinted during the younger igneous pulses. The latter is identified as a new tectono-magmatic basement province (IV in Fig. 1) to differentiate it from other parts of the Egyptian basement, even though the definition of its southern limits will require further detailed studies in NW Arabia and Sinai.

Finally, these data permit us for the first time to identify an erosional unconformity that was developed early in the 
Pan-African evolution of N Afro-Arabia. Priem et al. (1984) produced $\mathrm{U}-\mathrm{Pb}$ zircon ages for granitic pebbles from metaconglomerates from the Sa'al and Kid areas (Fig. 1). The Sa'al metaconglomerate pebbles gave an upper intercept age of $757 \pm{ }_{20}^{28}$ Ma while the Kid pebbles gave an upper intercept age $735 \pm{ }_{22}^{28}$ Ma. These pebbles must have been eroded from a basement similar to that of the $780 \pm 50 \mathrm{Ma}$ terrane identified here. This is a further indication that much of the basement of Sinai and Jordan had been consolidated and was being subjected to uplift and erosion while processes of accretionary and extensional tectonics were continuing to the south and west.

\section{Conclusion}

The Precambrian basement exposed in Wadi Feiran records almost $200 \mathrm{Ma}$ of crustal growth. The emplacement of granodiorite at $782 \mathrm{Ma}$ is part of a major episode that resulted in the formation of large portions of the basement of Sinai, southern Israel, and Jordan at $780 \pm 50 \mathrm{Ma}$. This terrane was uplifted and eroded, supplying course debris to flanking basins. A second major episode is reflected in the formation of paragneisses at or slightly after $632 \mathrm{Ma}$; this may represent an eastern extension of tectonic and magmatic activity of this age, commonly found in the Eastern Desert of Egypt. Finally, extensional tectonism and magmatic activity accompanied the emplacement of $\mathrm{N} 30^{\circ}$ E-trending dyke swarms at $591 \mathrm{Ma}$ and related A-type granites. Although it is becoming increasingly clear that an older foreland (or accreted terrane?) existed in northernmost Afro-Arabia early in the Pan-African, there is still no evidence for either a pre-Pan-African foreland or reworked pre-Pan-African basement in northernmost Afro-Arabia east of the River Nile.

Field work in Sinai was made possible by the co-operative research programme of Professors E. M. El-Shazly and W. H. Kanes (NSF INT-7801469). Laboratory research was supported by NSF EAR-8205802. The assistance of David Voegeli in the field and in the laboratory was appreciated. David Mittlefehldt made it possible to review critical parts of Miriam Bielski's dissertation. The comments of P. D. Fullager, H. N. A. Priem, A. Reymer, J. S. Stacey and two anonymous reviewers are gratefully acknowledged. This is University of Texas at Dallas Programs in Geosciences contribution number 499 .

\section{References}

BENDER, F. 1974. Explanatory notes on the geological map of the Wadi Araba, Jordan. Geologische Jahrbuch, B10, 3-62.

BIELSKI, M. 1982. Stages in the evolution of the Arabian-Nubian massif in Sinai. PhD thesis, Hebrew University.

- JäGer, E. \& STEInITZ, G. 1979. The geochronology of Iqna Granite (Wadi Kid Pluton), Southern Sinai. Contributions to Mineralogy and Petrology, 70, 159-65.

Cahen, L., SNelling, N. J., Delhal, J. \& Vall, J. R. 1984. The Geochronology and Evolution of Africa. Oxford University Press, London.

Claesson, S., Pallister, J. S. \& Tatsumoto, M. 1984. Samariumneodymium data on two late Proterozoic ophiolites of Saudi Arabia and implications for crustal and mantle evolution. Contributions to Mineralogy and Petrology, 85, 244-52.

Clark, M. D. 1985. Late Proterozoic crustal evolution of the Midyan region, northwestern Saudi Arabia. Geology, 13, 611-5.

Cooper, J. A., Stacey, J. S., Stoeser, D. G. \& Fleck, R. J. 1979. An evaluation of the zircon method of isotopic dating in the southern Arabian craton. Contributions to Mineralogy and Petrology, 68, 429-39.

Dixon, T. H. 1981. Age and chemical characteristics of some pre-Pan-African rocks in the Egyptian Shield. Precambrian Research, 14, 119-33.

Durverman, H. J., Harris, N. B. W. \& Hawkesworth, C. J. 1982. Crustal accretion in the Pan African: $\mathrm{Nd}$ and $\mathrm{Sr}$ isotope evidence from the Arabian Shield. Earth and Planetary Science Letters, 59, 315-26.

Elbayoumi, R. M. A. \& Greilna, R. 1984. Tectonic evolution of a Pan-African plate margin in southeastern Egypt-a suture zone overprinted by low angle thrusting?. In: KLERKX, J. \& MiCHOT, J. (eds) African Geology. Tervuren, 47-56.

EL-Gaby, S. \& AHMED, A. M. A. 1980. The Feiran-Solaf gneiss belt, SW of Sinai, Egypt. Bulletin of the Institute of Applied Geology, King Abdulaziz University (Jeddah), 4, 95-105.

EL-ManharawY, M.S. 1977. Geochronological investigation of some basement rocks in the Central Eastern Desert, Egypt, between Lat. $25^{\circ}$ and $26^{\circ} \mathrm{N}$. PhD thesis, University of Cairo.

EL-RAMLY, M. F. 1972. A new geological map for the basement rocks in the eastern and southwestern deserts of Egypt. Annals of the Geological Survey of Egypt, 2, 1-18.

El-Shazly, E. M., Hashad, A. H., Sayyah, T. A. \& Bassyuni, F. A. 1973. Geochronology of the Abu Swayel area, south Eastern Desert. Egyptian Journal of Geology, 17, 1-18.

Engel, A. E. J,, Dixon, T. H. \& Stern, R. J. 1980. Late Precambrian evolution of Afro-Arabian crust from ocean arc to craton. Bulletin of the Geological Society of America, 91, 699-706.

Eyal, M., Bartov, Y., Shimron, A. E. \& Bentor, Y. K. 1980. Sinai-Geological map $(1: 500,000)$. Geological Survey of Israel.

Fitches, W. R., Graham, R. H., Hussein, I. M., Ries, A. C., Shackleton, R. M. \& Price, R. C. 1983. The Late Proterozoic ophiolite of Sol Hamed, NE Sudan. Precambrian Research, 19, 385-411.

Fleck, R. J., Greenwood, W. R., Hadley, D. G., Anderson, R. E. \& SCHMIDT, D. L. 1980. Rubidium-strontium geochronology and plate-tectonic evolution of the southern part of the Arabian Shield United States Geological Survey Professional Paper, 1131.

Freund, R., Garfunkel, Z., Zak, I., Goldberg, M., Weissbrod, T. \& Derin, B. 1970. The shear along the Dead Sea Rift. Philosophical Transactions of the Royal Society, London, 267A, 107-30.

Fullagar, P. D. 1980. Pan-African age granites of northeastern Africa: new or reworked sialic materials? In: SALEM, M. J. \& BUSREWIL, M. T. (eds) Geology of Libya, Second symposium on the Geology of Libya, 3 Academic Press, London, 1051-58.

Gass, I. G. 1977. The evolution of the Pan African crystalline basement in NE Africa and Arabia. Journal of the Geological Society, London, 134, 129-38.

HALPERN, M. 1980. Rb-Sr 'Pan-African' isochron ages of Sinai igneous rocks. Geology, 8, 48-50.

- \& TRISTAN, N. 1981. Geochronology of the Arabian-Nubian Shield in southern Israel and eastern Sinai. Journal of Geology, 89, 639-48.

Harris, N. B. W., Hawkesworth, C. J. \& Ries, A. C. 1984. Crustal evolution in northeast and east Africa from model Nd ages. Nature, 309, $773-6$.

Hashad, A. H. M., Sayyah, T. A., El-Kholy, S. B. \& Youssef, A. 1972. $\mathrm{Rb} / \mathrm{Sr}$ isotopic age determination of some basement Egyptian granites. Egyptian Journal of Geology, 16, 269-81.

HEDGE, C. E. 1984. Precambrian geochronology of part of northwestern Saudi Arabia, Kingdom of Saudi Arabia. United States Geological Survey Open File Report, 84-381.

Hume, W. F. 1934. Geology of Egypt, vol. 2, part 1. The Metamorphic Rocks. Geological Survey of Egypt.

JARAR, G., BaumanN, A. \& WACHENDORF, H. 1983. Age determination in the Precambrian basement of the Wadi Araba area, southwest Jordan. Earth and Planetary Science Letters, 63, 292-304.

JOHNSON, P. R. 1983. A preliminary lithofacies map of the Saudi Arabian Shield: an interpretation of the lithofacies and lithostratigraphy of the late Proterozoic layered rocks of Saudi Arabia (1:1,000,000 scale, in two sheets). Saudi Arabian Directorate General of Mineral Resources, Technical Record RF-TR-03-2.

KLEMENIC, P. M. 1985. New geochronological data on volcanic rocks from northeast Sudan and their implication for crustal evolution. Precambrian Research, 30, 263-76.

KLERKX, J. \& DeUTSCH, S. 1977. Resultats préliminaires obtenus par la methode $\mathrm{Rb} / \mathrm{Sr}$ sur l'âge des formations Prêcambriennes de la région d'Uweinat (Libye). Musee Royal de l'Afrique Centrale, Annual Report $1976,83-94$.

KRöner, A. 1984. Late Precambrian plate tectonics and orogeny: a need to redefine the term Pan-African. In: KLerkx, J. \& Michor, J. (eds) African Geolagy. Tervuren, 23-6.

- 1985. Ophiolites and the evolution of tectonic boundaries in the late 
Proterozoic Arabian-Nubian Shield of Northeast Africa and Arabia. Precambrian Research, 27, 277-300.

Ludwig, K. R. 1980. Calculation of uncertainties of U-Pb isotope data. Earth and Planetary Science Letters, 46, 212-20.

MASSEY, K. W. 1984. Rubidium-strontium geochronology and petrography of the Hammamat formation in the northeastern desert of Egypt. MSc thesis, University of Texas at Dallas.

Mittlefehldt, D. W. \& Reymer, A. P. S. 1986. Sinai granites: a discussion of their origin based on petrological and $\mathrm{Sr}$-isotopic constraints. Israel Journal of Earth Science, 35, 40-50.

Priem, H. N. A., Eyal, M., Hebeda, E. H. \& Verdurmen, E. A. Th. 1984. $\mathrm{U}-\mathrm{Pb}$ zircon dating in the Precámbrian basement of the Arabo-Nubian Shield of the Sinai Peninsula. A progress report. Terra Cognita, Special Issue E.C.O.G. VIII, 30-1.

Schandelmeir, H., Darbyshire, D. P. F. \& Harms, U. in press. Proterozoic crustal reworking of the continental NE African plate in southern Egypt and northern Sudan. Precambrian Research.

Schürmann, H. M. E. 1966. The Pre-cambrian along the Gulf of Suez and the Northern Part of the Red Sea. E. J. Brill, Leiden.

SHIMRON, A. E. 1980. Proterozoic island arc volcanism and sedimentation in Sinai. Precambrian Research, 12, 437-58.

Stacey, J. S. \& Hedge, C. E. 1984. Direct evidence for early Proterozoic crust in the eastern Arabian Shield. Geology, 12, 310-3.

- \& Kramers, J. D. 1975. Approximation of terrestrial lead isotope evolution by a two-stage model. Earth and Planetary Science Letters, 26, 207-21.

, Stoeser, D. B., Greenwood, W. R. \& Fischer, L. B. 1984. U-Pb zircon geochronology and geological evolution of the Halaban-Al Amar region of the eastern Arabian Shield, Kingdom of Saudia Arabia. Journal of the Geological Society, London, 141, 1043-55.

Stern, R. J. 1985. The Najd Fault System of Saudi Arabia and Egypt: a late Precambrian rift-related transform system? Tectonics, 4, 497-511.

- GottFried, D. G. \& Hedge, C. E. 1984. Late Precambrian rifting and crustal evolution in the Northeastern Desert of Egypt. Geology, 12, 168-72.

— \& HedGe, C. E. 1985. Geochronological and isotopic constraints on late Precambrian crustal evolution in the Eastern Desert of Egypt. American Journal of Science, 285, 97-127.

Stoeser, D. B. \& CAMP, V. E. 1985. Pan-African microplate accretion of the Arabian Shield. Bulletin of the Geological Society of America, 96, 817-26.

Sturchio, N. C., Sultan, M. \& Batiza, R. 1983a. Geology and origin of Meatiq Dome, Egypt: a Precambrian metamorphic core complex? Geology, 11, 72-6.

Sturchio, N., Sultan, M., Sylvester, P., Batiza, R., Hedge, C., El Shazly, E. M. \& ABDel-MEguid, A. 1983b. Geology, age, and origin of the Meatiq Dome: implications for the Precambrian stratigraphy and tectonic evolution of the Eastern Desert of Egypt. Bulletin of the Institute of Applied Geology, King Abdulaziz University (Jeddah), 6, 127-43.

VOEGELI, D. A. 1985. The origin of composite dike rocks from the Northeastern Desert and Sinai, Egypt. MSc thesis, University of Texas at Dallas.

YORK, D. 1969. Least squares fitting of a straight line with correlated errors. Earth and Planetary Science Letters, 5, 320-4.

Received 16 June 1986; revised typescript accepted 29 September 1986. 